\title{
VERBA TURUNAN DALAM BAHASA JAWA
}

\author{
Siti Mulyani \\ FBS Universitas Negeri Yogyakarta \\ email: Siti_mulyani@uny.ac.id
}

\begin{abstract}
This study aims to describe the affixation process, semantic change in the formation of derived verbals, and the functions that such verbals can serve in Javanese sentences. It employed the descriptive approach. The data were collected from sentences the Djaka Lodang magazine and spoken discourse in society. They were collected through reading, listening, and recording. The data were analyzed using the substitution method. The findings show that derived verbals in Javanese can be formed using prefixes $N_{-}, m a N-, k a-, k e-$, di-l dipun-, and bawa ha, infixes -um- and -in-, suffixes $-i,-a,-e n,--a n,-n a,-a n a$, and -akel-aken, confix ka-l-an, and combined affixes N-/ -i, N-/ -ake, N- / -a, N- / -na, N-/ -ana, di-/ -i, di- / -a, di- / -na, di- / ake, -in-/ -an, -in-/ -ake, -in-/ -ana, and -um-/ -a. Derived verbs in Javanese can be both active verbs and passive verbs. They can function as subjects, predicates, objects, complements, or adverbials in sentences.
\end{abstract}

Keywords: derived verbals, affixation process, semantic change

\section{PENDAHULUAN}

Kalimat merupakan bagian terkecil dari suatu ujaran atau wacana yang mengungkapkan pikiran yang utuh. Satu kesatuan gagasan yang disampaikan melalui kalimat tersebut apabila dilihat dari struktur kalimatnya tersusun atas unsur subjek, predikat, objek, keterangan, dan pelengkap. Pembagian kalimat menjadi unsur subjek, predikat, objek keterangan, dan pelengkap merupakan pemerian kalimat atas fungsi-fungsinya.

Subjek dalam suatu kalimat merupakan pokok pembicaraan, dalam bahasa Jawa biasanya subjek itu diduduki oleh kata yang berkategori benda atau frasa benda, namun kategori kata yang lain juga dapat menempati fungsi subjek, sebagai misal kata/ frasa kerja, kata/ frasa bilangan, atau kata/ frasa keadaan pun juga dapat menempati fungsi subjek. Predikat merupakan bagian yang menerangkan pokok pembicaraan dan merupakan bagian inti suatu kalimat, yang biasa mengisi fungsi predikat berupa kata yang berkategori kerja atau frasa kerja. Kata yang berkategori kerja dalam bahasa Jawa selain menduduki fungsi predikat dalam suatu kalimat juga dapat menduduki fungsi sebagai subjek, objek, pelengkap, ataupun keterangan. Dengan demikian, kata kerja dalam bahasa Jawa kemunculannya akan sering mengingat bahwa kata kerja tersebut dapat menduduki berbagai fungsi dalam kalimat.

Dilihat dari bentuknya kata kerja dapat dibedakan menjadi dua, yaitu verba asal dan verba turunan. Yang dimaksud dengan verba asal adalah kata yang berkategori verba namun duilihat dari bentuknya kata tersebut dapat berdiri sendiri tanpa mengalami proses afiksasi, sedang verba turunan merupakan kata yang berkategori verba/ kerja dilihat dari bentuknya merupakan kata yang telah mengalami proses afiksasi.

Pembentukan verba turunan dengan proses afiksasi dalam bahasa 
Jawa sangat bervariasi, dengan kata lain proses afiksasi dalam bahasa Jawa untuk membentuk kata yang berkategori verba turunan sangat beragam. Keragaman bentuk tersebut nampak dari suatu kata dari jenis kata tertentu dapat dibentuk verba turunan sangat banyak. Sebagai misal, sapu "sapu" sebagai suatu kata yang berkategori nomina (benda) dapat diturunkan menjadi lebih dari 10 kata verba turunan. Beberapa contoh verba yang duturunkan dari bentuk dasar sapu antara lain; nуари 'menуари', nуариа 'menyapulah', nyaponana 'seandainya menyapu', nyapokna 'sapukan', nyapokake menyapukan', disapu 'disapu', disapua 'meskipun disapu', disaponi 'telah/ sedang disapu', disaponana 'seandainya disapu', disapokake 'disapukan oleh', dan saponana 'sapulah'. hal itu disebabkan adanya berbagai jenis afiks yang dapat dipergunakan untuk membentuk verba turunan dalam bahasa Jawa. Selain itu, berbagai kategori kata dapat diturunkan menjadi verba turunan dengan proses afiksasi.

Keragaman pembentukan verba turunan tersebut merupakan salah satu indikator kekayaan kosa kata dalam bahasa Jawa yang di dalamnya terkandung keunikan yang hanya dimiliki oleh bahasa Jawa khususnya terkait dengan pembentukan verba turunan. Namun dalam kelebihan tersebut juga memunculkan berbagai permasalahan. Permasalahan tersebut terkait dengan bagaimana proses pembentukan dan pemakaiannya untuk berkomunikasi dalam kehidupan sehari-hari di masyarakat. Hal itu sangat dirasakan oleh generasi muda atau para pembelajar bahasa Jawa.

Bertolak pada permasalahan tersebut di atas, maka perlu diadakan penelitian yang lebih mendalam tentang verba turunan bahasa Jawa. Dengan penelitian ini diharapkan permasalahan yang terkait dengan proses afiksasi, pe- rubahan makna dalam pembentukan verba turunan serta fungsi yang dapat didudukinya dalam bahasa Jawa.

\section{METODE}

Data dalam penelitian ini berupa kata yang kategori verba turunan yang didapatkan dari media cetak berbahasa Jawa serta pemakaian bahasa Jawa sebagai sarana komunikasi di masyarakat di Yogyakarta. Sumber data pada penelitian ini adalah majalah "Djaka Lodang" dan "Penyebar Semangat" yang diterbitkan pada bulan Januari - Mei tahun 2008 dan percakapan dalam masyarakat Yogyakarta.yang mempergunakan bahasa Jawa sebagai sarana komunikasi. Dalam pengumpulan data digunakan teknik dasar sadap dan teknik lanjutan adalah baca catat dan simak catat.

Metode analisis data yang dipergunakan dalam penelitian ini adalah metode agih karena unsur penentunya adalah bahasa itu sendiri dengan menggunakan teknik bagi unsur langsung dan baca markah. Pemakaian teknik bagi unsur langsung dipergunakan dengan membagi konstituen-konstituen dalam kalimat untuk menentukan fungsi sintaktis yang diduduki oleh verba turunan. Sedang teknik analisis baca markah dipergunakan untuk memaparkan proses pembentukan verba turunan beserta maknanya. Teknik baca markah dilakukan dengan melihat secara langsung pemarkah yang melekat pada data yang dapat dipergunakan untuk medeskripsikan kejatian data, dalam hal ini akan dilakukan secara morfologis dan sintaktis.

Untuk mengukur keabsahan data digunakan validitas semantik dan dengan trianggulasi dalam hal ini data dicek/ dicocokkan dengan teori yang relevan. Reliabilitas dicapai dengan pengamatan mendalam secara terus menerus. 


\section{HASIL DAN PEMBAHASAN}

Verba turunan dalam bahasa Jawa memiliki berbagai bentuk, makna dan fungsi dalam kalimat. Berikut akan dipaparkan tentang perubahan bentuk dan makna dalam proses pembentukan verba turunan serta fungsinya dalam kalimat berbahasa Jawa.

Proses Pembentukan Verba Turunan dan Maknanya

Bentuk, perubahan kategori serta perubahan makna yang terkandung dalam verba turunan dalam bahasa Jawa dapat diketahui dengan melihat proses pembentukan verba turunan tersebut. Dalam bahasa Jawa terdapat 5 (lima) afiks yang dapat menurunkan verba, yaitu prefiks, infiks, sufiks, konfiks, serta gabungan beberapa afiks. Afiks pembentuk verba turunan nampak pada tabel 1 .

Tabel 1 Afiks Pembentuk Verba Turunan dalam Bahasa Jawa

\begin{tabular}{ccccc}
\hline Prefiks & Infiks & Sufiks & Konfiks & Gabungan \\
\hline$N-$ & $-u m-$ & $-i$ & $k a-/-a n$ & $N-/-i$ \\
$m a N-$ & $-i n-$ & $-a$ & & $N-/-a k e$ \\
$k a-$ & $-e n$ & & $N-/-a$ \\
$k e-$ & & $-a n$ & & $N-/-n a$ \\
$d i-/$ dipun- & & $-n a$ & & $N-/-a n a$ \\
$a-$ & $-a n a$ & & $d i--i$ \\
$m a-$ & $-a k e /-a k e n$ & & $d i--a$ \\
$m e r-$ & & $d i--a n a$ \\
& & & $d i--n a$ \\
& & & $d i-a k e$ \\
& & & $-i n-/-a n$ \\
& & & $-i n-/-a k e$ \\
& & & $-i n-/-a n a$ \\
& & & $-u m-/-a$ \\
\hline
\end{tabular}

Dari tabel di atas, tampak berbagai macam afiks dalam bahasa Jawa yang dapat membentuk verba turunan. Prefiks pembentuk verba dalam bahasa Jawa berupa N- yang mempunyai alomorf am-, an-, ang-, dan any- , prefiks maN- , ka- , ke- , di-l dipun- , dan bawa ha yang mempunyai alomorf $a-, m a-$, dan mer-. Afiks sisipan yang dapat membentuk verba turunan adalah -um- dan -in-. Verba turunan dapat dibentuk dengan melekatkan sufiks pada kata dasar, sufiks yang membentuk verba turunan dalam bahasa Jawa adalah $-i,-a,-e n,--$ an, -na,-ana, dan-akel-aken. Konfiks yang dapat membentuk verba turunan adalah $k a-l-a n$. Afiks gabungan yang dapat membentuk verba turunan dalam bahasa Jawa sangat bervariasi afiks-afiks tersebut adalah $N-/-i, N-/$-ake, N- / $-a$, N- / -na, N-/ -ana, di-/ -i, di- / -a, di- / -na, di- / - ake, -in-/ -an, -in-/ -ake, -in-/ -ana, dan $-u m-/-a$.

\section{Verba Turunan dengan Prefiks}

Dalam bahasa Jawa ada beberapa prefiks yang dapat membentuk verba turunan. Prefiks tersebut adalah $N_{-}$, $k a-, k e-$, di-/ dipun-, dan bawa ha. Verba turunan yang dapat dibentuk dengan prefiks $N$ - dengan alomorf an-, am-, ang-, dan any- serta prefiks-prefiks lain pembentuk verba turunan terurai berikut ini. 
Nanging menawa banjur kemurahen sing ateges ora bisa nutup ragad operasional....'Tetapi kalau terlalu murah artinya tidak dapat mencukupi kabutuhan operasional.....' ( DL, 36, 3 Pebruari 2008: 3, 1, 2)

Data di atas terkandung kata nutup yang berasal dari kata dasar tutup mendapat prefix $N$ dengan alomorf an- sehingga menjadi kata anutup. Kata tersebut dalam pemakaian sehari-hari menjadi nutup 'menutup' yaitu melakukan pekerjaan seperti yang disebutkan dalam bentuk dasarnya. Demikian pula data berikut.

Malah ing dalan Brikjen Katamso, sacedake Purawisata ana papan kanggo mbuwang uwuh digambari wong kang mithes irung 'Malahan di jalan Brigjen Katamso dekat Purawisata ada tempat pembuangan sampah yang digambari orang yang memencet hidungnya'(DL, 49, 3 Mei 2008: 8)

Data tersebut mengandung kata mithes kata itu berupa verba turunan yang dibentuk dari kata dasar pithes dilekati prefiks $N$ - dengan alomorf amsehingga menjadi amithes. Dalam keseharian kata tersebut lazim digunakan dengan bentuk mithes 'menekan ujung hidung dengan ibu jari dan jari telunjuk' yaitu melakukan pekerjaan seperti yang disebut dalam bentuk dasarnya.

Awit mekaripun teknologi jaman samangke sampun ngrangkeng nalurinipun saben titah, akibatipun boten wonten keselarasan batin 'Karena perkembangan teknologi jaman sekarang sudah membelenggu naluri setiap orang, sebagai akibatnya tidak ada keselarasan batin' ( DL, 36, 3 Pebruari 2008: 6)

Kutipan di atas mengandung kata ngrakeng merupakan sebuah kata yang berjenis verba turunan yang dibentuk dari kata dasar krangkeng Proses morfologi pembentukan kata ngrangkeng adalah kata dasar krangkeng mendapat prefix $\mathrm{N}$ - dengan alomorf ang-sehingga menjadi angrangkeng dalam keseharian menjadi ngrangkeng 'membatasi gerak dengan krangkenng', yang biasanya ditempatkan di krangkeng adalah binatang buas.

Nanging dikantheni kupiya sing temenan bisa nyuda omongan kang rasane pedhes iku mau 'Tetapi dengan upaya yang sungguh-sungguh dapat mengurangi omongan yang pedas/ menyakitkan itu'( DL, 36, 3 Pebruari 2008: 4)

Pada petikan di atas mengandung kata nyuda merupakan kata berjenis verba turunan dari bentuk dasar suda 'kurang' mendapat prefix $\mathrm{N}$ - dengan alomorf any- sehingga menjadi anyuda yang dalam kehidupan sehari-hari menjadi nyuda' mengurangi'

Madege Pepadi "Pandhawa Tama" iki sawise oleh pelimpahan saka Pengurus Sementara organisasi masa bakti 19852005 sing tetela aktif lan ora kacathet ana ing Dinas Pariwisata lan Kebudhayaan 'Berdirinya Pepadi "Pandhawa Tama" itu setelah mendapat limpahan dari Pengurus Sementara organisasi masa bakti $1985-2005$ yang ternyata aktif dan tidak tercatat oleh Dinas Pariwisata dan Dinas Kabudayaan' (DL, 36, 3 Pebruari 2008: 7)

Data di atas mengandung kata kacathet 'tercatat' yang merupakan suatu kata berjenis verba turunan atau kata kerja pasif, kata itu diturunkan dari bentuk dasar cathet 'catat' mendapat prefiks $k a-$.

Sasampunipun kula kepanggih kalayan paduka tujuan kula dados kosok wangsul kalayan pakenipun kadang kula wredha inggih kala Arimba 'Setelah saya bertemu dengan paduka tujuan saya berkebalikan dengan perintah saudara tua saya yaitu kala Arimba' (DL, 49 , 3 Mei 2008: 17) 
Petikan di atas mengandung kata kepanggih 'bertemu'. Kata tersebut merupakan verba turunan yang dibentuk dari kata dasar panggih 'temu' dengan mendapat prefiks $k e-$, prefiks itu membentuk verba turunan/ kata kerja pasif yang mengandung makna melakukan pekerjaan dengan tidak disengaja.

Sadurunge diwedharake, dipikir luwih dhisik, endi omongan kang becik lan ora prayoga 'Sebelum diutarakan, dipikir terlebih dahulu, mana perkataan yang baik dan mana perkataan yang tidak baik' ( DL, 36, 3 Pebruari 2008: 4)

Pada data di atas mengandung kata dipikir 'dipikir' yang merupakan verba turunan berjenis kata kerja pasif yang diturunkan dari bentuk dasar pikir 'pikir' mendapat prefiks di-. Prefiks tersebut membentuk kata kerja pasif.

Andadosna kauningan Raden, sejatosipun dhateng kula ngriki menika dipunkengken kadang kula wredha inggih pun Arimba menika mikut paduka sakadang sadaya badhe pun mangsa, awit sampun sawetawis dinten dereng angsal memangsan 'Harap menjadikan periksa Raden.sebenarnya kedatangan saya ini diperintah saudara tua saya yaitu Arimba untuk meringkus anda semua klarena sudah beberapa waktu tidak mendapatkan makanan' (DL, 49, 3 Mei 2008: 17)

Petikan di atas mengandung kata dipunkengken 'diperintah' yang berasal dari bentuk dasar kengken mendapat prefiks dipun-. Prefiks dipun- mempunyai fungsi dan makna seperti prefiks di- yaitu membentuk verba turunan. kata kerja pasif biasanya yang melaksanakan pekerjaan itu orang lain. Satuan lingual kengken berasal dari akar kata ken diulang sehingga menjadi kenken dalam kehidupan sehari-hari menjadi kengken 'perintah'. Dipunkengken dalam konteks data di atas bermakan pelaku melakukan pekerjaan untuk keperluan orang yang menyuruh.
Mesthi wae kahanan ngono iku agawe runtik penggalihe Pangeran Benawa 'Tentu saja keadaan seperti itu membuat marahnya Pangeran Benawa' (DL, 49 , 3 Mei 2008: 1)

Kutipan di atas mengandung kata agawe 'membuat' yang diturunkan dari bentuk dasar gawe ' buat' mendapat prefiks $a^{-}$, prefiks itu berfungsi membentuk verba turunan/ kata kerja aktif senada dengan prefiks be (r) dalam bahasa Indonesia.

Pramila sumangga para trahing awara tapa ingkang tansah ngudi jatining kautaman, nggesangaken raos malih kanthi sinau basa 'Karena itu mari orangorang keturunan golongan pertapa yang selalu mengupayakan keutamaan sejati, mengidupkan rasa dengan mempelajari bahasa' (DL, 14 , 6 September 2008: 48)

Petikan di atas mengandung kata awara merupakan verba turunan yang berasal dari bentuk dasar wara 'golongan' mendapat prefiks $a$ - yang menurut konteksnya mempunyai makna ber-/ termasuk dalam. Kata awara berarti bergolongan.

Raden Jungkung Mardeya aprasapa. boten badhe nambut silaning akrami menawi boten kaliyan Dewi Wara Srikandhi " Raden Jangkung Mardeya berjanji tidak akan menikah kalau tidak dengan dewi Wara Srikandhi' DL. 14, 6 September 2008:17)

Pada data di atas mengandung kata aprasapa yang diturunkan dari bentuk dasar prasapa 'janji' mendapat prefiks $a$-. Prefiks $a$-tersebut berfungsi mengubah kata benda menjadi kata kerja aktif yang mempunyai makna melakukan perbuatan seperti yang diungkapkan pada bentuk dasarnya.

Wanita kang sesantine, makarya nganti tekan puputing umur iki, duwe simbul kembang Gondosuli 'Wanita yang bersemboyan bekerja sampai akhir hayat ini mempunyai simbul bunga Gondosuli' ( DL, 36, 3 Pebruari 2008: 7) 
Pada petikan di atas mengandung kata makarya 'bekerja' berasal dari bentuk dasar karya 'buat' mendapat prefiks ma-. Prefiks itu berfungsi membentuk verba turunan yang mempunyai makna melakukan suatu pekerjaan seperti yang disebut dalam bentuk dasarnya.

Jam setengah sanga Sumi wis mertamu ana daleme wong tuwane Karjono 'Jam setengah sembilan Sumi sudah bertamu di rumah orang tua Karjono' (DL 14, 6 Pebruari 2008: 25)

Pertikan tersebut mengandung kata mertamu yang merupakan verba turunan yang berasal dari bentuk dasar tamu 'tamu' mendapat prefiks mer-. Prefiks tersebut mengubah kata benda menjadi verba turunan dengan makna melakukan suatu pekerjaan/ aktivitas.

\section{Verba Turunan dengan Infiks}

Afiks sisipan/infiks yang dapat membentuk verba turunan dalam bahasa Jawa adalah -um- dan -in-. Berikut verba turunan yang dibentuk dengan proses penambahan sisipan/infiks dalam bahasa Jawa.

Sira kabeh dadia sabecik-becike umat kang tumitah ana ing donya ' Kamu semua jadilah sebaik-baiknya umat yang diciptakan di dunia' (DL, 36, 3 Pebruari 2008: 18)

Takdir iku wis ginaris dening Gusti Kang Murbeng Dumadi 'Takdir itu sudah ditetapkan oleh Tuhan Yang Menguasai Kehidupan (DL, 49, 3 Mei 2008: 40)

Kalimat pertama kutipan di atas mengandung kata tumitah 'diciptakan/ tercipta' yang berasal dari kata titah 'yang diciptakan Allah' mendapat infiks/ seselan -um- yang membentuk verba intransitif. Kata ginaris pada kutipan itu berasal dari bentuk dasar garis 'garis' mendapat infiks -in- yang berfungsi membentuk kata kerja pasif bermakna melakukan suatu pekerjaan, biasanya yang melaksanakan pekerjaan tersebut orang lain atau bukan diri sendiri.

\section{Verba Turunan dengan Sufiks}

Afiks yang berbentuk sufiks dalam bahasa Jawa yang dapat membentuk verba turunan adalah $-i,-a$, $-e n$, --an, -na, -ana, dan -akel-aken. Verba turunan yang dapat dibentuk dengan sufiks tersebut terurai berikut ini.

"Inggih paman, mula gek ndang dirangket mawon... taleni... mawon... thuthuki sisan..." warna-warna panguwuhe para Kurawa "'Iya Paman, makanya cepat dibelenggu saja... diikat... saja... dipukuli sekalian" bermacammacam celoteh para Kurawa"' ' DL 14 6 September 2008: 17)

Petikan di atas mengandung kata taleni 'ikatlah' dan thuthuki 'pukulah'. Kedua kata tersebut merupakan verba turunan dengan bentuk dasar ditambah sufiks $-i$. Dalam bahasa Jawa kata yang mendapat imbuhan $-i$ akan berubah menjadi verba turunan dengan makna perintah supaya orang lain melaksanakan suatu perbuatan. Kata taleni berasal dari bentuk dasar tali 'tali' mendapat sufiks - $i$ mempunyai makna ikatlah. Proses morfologis pembentukan kata thuthuki 'pukullah' berasal dari kata dasar thuthuk'pukul' mendapat sufiks - $i$ yang bermakna pukullah.

Raden sakmenika kersaa paduka kula bekta oncat saking riki... "Raden sekarang sudilah paduka saya bawa pergi dari sini...' (DL, 49 , 3 Mei 2008: 17)

Data di atas mengandung kata kersaa berasal dari bentuk dasar kersa 'mau' mendapat sufiks - a yang merupakan verba turunan yang mempunyai makna pengharapan supaya mau.

Tangia dhisik, takcritani ! 'Bangunlah dahulu saya bilangin!'(DL, 49, 3 Mei 2008: 15) 
Kutipan di atas mengandung kata tangia 'bangunlah' yang dibentuk dari bentuk dasar tangi 'bangun' mendapat sufiks $-a$, kata tersebut mengandung makna perintah supaya bangun.

Sira kabeh dadia sabecik-becike umat kang tumitah ana ing donya durung bisa nguwali kahanan iki 'Kamu semua meskipun jadi umat yang baik-baik yang tercipta di dunia belum dapat mengatasi keadaan ini' (DL, 36, 3 Pebruari 2007: 18)

Data di atas mengandung kata dadia 'meskipun jadi' yang diturunkan dari bentuk dasar dadi 'jadi' mendapat sufiks - $a$ sebagai pembentuk verba dengan makna pengandaian.

Sedulur, ayo gek ndang eling ' Saudaraku, lekas ingatlah'

wus tekan titi mangsane 'telah tiba saatnya'

biraten kemerenmu 'hilangkan keirian$\mathrm{mu}^{\prime}$

ruwaten srakahmu 'ruwatlah keserakahanmu' (DL 1727 September 2008: 35)

Kutipan di atas mengandung kata biraten 'buanglah' dan ruwaten 'ruwatlah', kedua kata tersebut termasuk verba turunan dengan penambahan sufiks -en yang berfungsi sebagai pembentuk kata kerja yang mengandung makna perintah atau imperatif. Kata biraten berasal dari bentuk dasar birat 'hilang' mendapat sufiks - en sedang ruwaten berasal dari bentuk dasar ruwat mendapat sufiks -en.

"Pasrahna kabeh marang Gusti Allah," mangkono ujare pak Suta. "Serahkan semuanya kepada Allah" ', begitu kata pak Suta' (DL 14, 6 September 2008: 15)

Petikan di atas mengandung kata pasrahna 'serahkan' merupakan verba turunan dari bentuk dasar pasrah 'serah' mendapat sufiks $-n a$, mempunyai makna perintah atau imperatif atau perintah agar orang lain melakukan sesuatu se- perti pada bentuk dasarnya yaitu pasrah 'serah'.

Kerepana kokjak nyang omah, aku ben saya kenal "Seringlah kau ajak ke rumah agar saya semakin kenal' (DL 15, 9 September 2008: 34)

Kutipan tersebut mengandung kata kerepana 'seringlah' merupakan verba turunan dari bentuk dasar kerep 'sering' mendapat sufiks - ana yang berfungsi membentuk verba turunan dengan makna imperatif atau perintah.

Minangka organisasi sing nembe lair, sajrone ngayahi jejibahan melu mekarake lan nglestarekake seni wayang kulit gedhe utawa cilik isih nemahi akeh pepalang 'Sebagai organisasi yang baru lahir, dalam melaksanakan kewajiban ikut mengembangkan dan melestarikan seni wayang kulit besar atau kecil masih menemui rintangan' ( DL, 36, 3 Pebruari 2008: 7)

Data di atas mengandung kata mekarake 'mengembangkan' merupakan verba turunan yang diturunkan dari bentuk dasar mekar 'kembang' mendapat sufiks -ake yang berfungsi membentuk verba aktif transitif.

\section{Verba Turunan dengan Afiks Gabungan}

Verba turunan dalam bahasa Jawa dapat dibentuk dengan proses melekatkan beberapa afiks yang berupa afiks gabungan pada bentuk dasar. Afiks gabungan yang dapat membentuk verba turunan dalam bahasa Jawa adalah N-/ -i, N-/ -ake, N- / -a, N- / -na, N-/ -ana, di-/ -i, di- / -a, di- / -ana, di- / ake, -in-/ -an, in-/-ake, -in-/ -ana, dan-um-/ --a. Berikut verba turunan yang dihasilkan dengan melekatkan afiks gabungan pada bentuk dasar.

Ki Patih nulya nyedhaki sang Tapa, uluk salam karo paring pangandhika 'Ki Patih kemudian mendekati sang pertapa, mengucapkan salam serta memberi perintah' ( DL, 36, 3 Pebruari 2008: 2) 
Kutipan di atas mengandung kata nyedhaki 'mendekati' merupakan verba turunan. Kata tersebut berasal dari bentuk dasarcedhak'dekat' mendapat prefiks $N$ - dengan alomorf an- sehingga menjadi anyedhak dalam keseharian menjadi nyedhak. Berikutnya kata nyedhak tersebut mendapat tambahan lagi sufiks $-i$ sehingga menjadi nyedhaki ' mendekati'. Afiks-afiks tersebut berfungsi membentuk verba aktif yang mempunyai makna melakukan perbuatan seperti yang disebutkan pada bentuk dasar dalam hal ini mendekat.

... ..yen kakehan anggone ngrahabi ing tutuk rasane kemetep, pedhes, lan krasa panas '... kalau terlalu banyak menyantap dalam mulut tersa pedas menyengat dan terasa panas' (DL, 36, 3 Pebruari 2008: 4)

Petikan tersebut mengandung kata ngrahabi 'menikmati' diturunkan dari bentuk dasar rahab 'santap' mendapat imbuhan $N$ - (dengan alomorf ang-) dan - $i$ sehingga menjadi ngrahabi. Imbuhan tersebut berfungsi membentuk verba turunan yang mempunyai makna melakukan pekerjaan seperti yang disebutkan pada bentuk dasar secara berkali-kali / repetitif.

..... dadi wajibing wong urip 'jadi kewajiban orang hidup'

kena rame ing pamrih 'boleh banyak keinginan'

nanging kudu ditimbangi rame ing gawe 'namun harus disertai dengan usaha'

saranane nyazwijia ........ ' sarananya dengan bersatulah.....(DL 17, 27 September 2008: 35)

Data di atas mengandung kata nyawijia 'satukanlah' yang merupakan verba turunan yang mempunyai makna perintah kepada orang lain supaya bersatu. Kata nyawijia berasal dari bentuk dasar sawiji mendapat prefiks $N$ - dengan alomorf any- sehingga menjadi nyawiji 'menyatu' kemudian kata terse- but mendapat sufiks - $a$ sehingga menjadi nyawijia yang bermakna bersatulah. Mas Her ngestokna dhawuh wong kang dianggep pinter mau mesthi kedadeane ora kaya ngene...' Mas Her andai melaksanakan perintah orang yang dianggap pandai tadi pasti kejadiannya tidak seperti ini....' (DL, 49, 3 Mei 2008: 15)

Petikan tersebut mengandung kata ngestokna 'andai melaksanakan' merupakan verba turunan. Kata ngestokna berasal dari dasar estu 'nyata' mendapat imbuhan -na menjadi estokna 'laksanakan' selanjutnya bentuk tersebut mendapat prefiks $N$ - (dengan alomorf ang-) sehingga menjadi ngestokna. Imbuhan $\mathrm{N}-$ - -na pada kata tersebut membentuk kata kerja dengan makna pengandaian.

Para maos ngematana kahanan akhirakhir iki temtu bisa nyawang ananing lukisan utawa gambar-gambar mural utawa lukisan ing tembok-tembok kang ana ing kutha Yogyakarta. 'Para pembaca amatilah keadaan akhirakhir ini tentu dapat melihat adanya lukisan atau gambar-gambar mural atau lukisan di tembok-tembok yang ada di kota Yogyakarta' (DL, 49, 3 Mei 2008: 8)

Data tersebut mengandung kata ngematana 'amatilah' yang merupakan kata berkategori verba turunan yang diturunkan dari kata emat 'tampak jelas' ditambah dengan dua afiks berupa prefiks $N$ - dengan alomorf ang- (ng-)/ -ana sehingga menjadi ngematana 'amatilah'. Afiks N-/ -ana pada kata tersebut membentuk verba turunan dengan makna perintah supaya melakukan pekerjaan seperti yang disebutkan dalam bentuk dasarnya dengan intensif yaitu emat sehingga ngematana mempunyai makna perintah supaya mengamati dengan baik-baik.

...dumeh calon penumpang isih akeh sing mbutuhake terus wae ditambahi penumpang tanpa ngelingi kapasitase '...karena calon penumpang masih 
banyak yang membutuhkan terus saja ditambah penumpangnya tidak memperdulikan kapasitasnya' ( DL, 36, 3 Pebruari 2008: 3)

Kutipan 29) mengandung kata ditambahi 'ditambah' yang merupakan verba turunan dari bentuk dasar tambah 'tambah' mendapat afiks di- sehingga menjadi kata ditambah berikutnya dilekati lagi sufiks - $i$. Afiks $d i-/-i$ pada kata ditambahi berfungsi membentuk kata kerja pasif yang mengandung makna melakukan perkerjaan.

Sosoke Nanta dipatria pengkuh jroning ati , bakal ilang kena lelara sindrom bintang 'Sosok Nanta meskipun dipatri kuat dalam hati akan hilang terkena penyakit sindrom bintang' (DL 13, 26 Agustus 2008: 45)

Petikan tersebut mengandung kata dipatria yang merupakan verba turunan berasal dari bentuk dasar patri 'patri' mendapat imbuhan di- sehinga menjadi dipatri selanjutnya mendapat sufiks $-a$. Kata dipatria merupakan verba turunan pasif yang mengandung makna meskipun dipatri.

Methungule Harmoko mau dikomentarana maneka warna dening wong akeh.... 'Munculnya Harmoko itu walaupun dikomentari orang banyak... (DL, 49 , 3 Mei 2008: 4)

Petikan di atas mengandung kata dikomentarana 'meskipun dikomentari' yang berkategori verba turunan berasal dari bentuk dasar komentar 'komentar' mendapat imbuhan di-/ -ana. Afiks di-/ -ana pada kata tersebut mengubah kata benda komentar menjadi kata kerja pasif yang mempunyai makna meskipun dikomentari.

Panyawange Nanta marang dheweke, kaya glathi kang siap ditujesna ing dhadha 'Pandangan Nanta kepadanya, seperti belati yang siap dihujamkan di dada' (DL 1326 Agustus 2008: 45)
Kutipan tersebut mengandung kata ditujesna 'dihujamkan' merupakan verba turunan yang berasal dari bentuk dasar tujes 'tusuk' mendapat imbuhan di-l -na. Afiks di-l -na pada kata ditujesna berfungsi membentuk verba turunan berupa verba pasif yang bermakna dilakukannya pekerjaan seperti yang disebutkan pada bentuk dasarnya, dalam hal ini afiks di- -na lebih menekankan cara seperti pada bentuk dasarnya.

Dheweke terus memburi njupuk wedang putih rong gelas, sing siji diulungake Nanta, dene sijine banjur dilangga dhewe 'Dia terus ke belakang mengambil dua gelas air putih, yang segelas diberikan kepada Nanta yang segelas terus ditenggaknya' (DL 1326 Agustus 2008: 45)

Pada data di atas mengandung kata diulungake 'diberikan' yang berkategori verba turunan berupa kata kerja pasif berasal dari bentuk dasar ulung 'beri' mendapat afiks di-l-ake. Afiks tersebut bermakna melakukan pekerjaan seperti yang disebutkan pada bentuk dasarnya dan berkaitan dengan orang lain.

Pangandikane sang Sinatriya Rama $i k u$ sinauran geter pater lan ndadekake mareme kang padha nekseni 'Ucapan Satria Rama disahut dengan hati yang bergetar dan membuat puas yang menyaksikan' (DL, 36, 3 Pebruari 2008: 16)

Kutipan tersebut mengandung kata sinauran 'disahut/ dibalas'. Kata sinauran berasal darti bentuk dasar saur 'sahut' mendapat afiks yang berupa infiks -in- dan akhiran -an. Afiks -in- -an berfungsi membentuk verba pasif.

Sadurunge diwedharake, pinikirake luwih dhisik, endi omongan kang becik lan ora prayoga 'sebelum diucapkan, dipikirkan terlebih dahulu mana perkataan yang baik dan mana yang kurang baik' ( DL, 36, 3 Pebruari 2008: 4) 
Petikan tadi mengandung kata pinikirake 'dipikirkan' yang berupa verba turunan dari bentuk dasar pikir 'pikir' mendapat afiks -in- -ake yang berfungsi membentuk verba turunan pasif bermakna dikenai suatu tindakan seperti yang disebutklan pada bentuk dasarnya.

Dewi Wara Srikandhi dening Ditya Bramastra den idak-idaka, cinokotana siyung kang mawa wisa datan pejah nanging saya dangu saya ageng...'Dewi Wara Srikandi oleh Raksasa Bramastra meskipun dinjak-injak, digigit dengan taring berbisa tidak mati tetapi semakin lama semakin besar...' (DL 146 September 2008: 16)

Data di atas mengandung kata $c i$ nokotana 'meskipun digigit' merupakan verba turunan yang berasal dari bentuk dasar cokot 'gigit' mendapat afiks -in- ana. Afiks -in-l -ana pada kata cinokotana berfungsi membentuk verba turunan pasif dengan makna meskipun digigit.

Pramila kawula jumurunga ing karsa Pangwasa Negara ing Mataram ngriki 'Maka dari itu rakyat/ penduduk dukunglah kehendak Penguasa Negara Mataran ini' (DL, 36, 3 Pebruari 2008: 2)

Kutipan tersebut mengandung kata jumurunga 'dukunglah' yang berasal dari bentuk dasar jurung 'dukung' mendapat afiks -um-/ - $a$. Afiks um- - a pada kata jumurunga 'dukunglah' berfungsi membentuk verba turunan aktif yang bermakna perintah supaya melakukan perbuatan seperti yang disebut pada bentuk dasar dalam hal ini perintah supaya memberi dukungan.

\section{Fungsi Verba Turunan dalam Kalimat}

Dalam bahasa Jawa verba turunan menduduki beberapa fungsi dalam kalimat. Fungsi-fungsi yang dapat diduduki oleh verba turunan terurai berikut ini.

\section{Verba Turunan sebagai Subjek}

Dalam bahasa Jawa verba turunan yang menduduki fungsi subjek tampak pada kalimat berikut ini.

Ngemis isih mencutake 'Meminta-

Subjek Predikat minta masih menggiyurkan' (DL No. 15 September 2008: 3)

Nyadran katindakake rong dina

$$
\text { Subjek Predikat }
$$

'Nyadran dilaksanakan dua hari'(DL

No.15 Keterangan September 2008: 13)

Dari kalimat di atas dapat diketahui bahwa fungsi subjek diduduki oleh kata yang berkategori verba turunan. Kalimat pertama ngemis 'meminta-minta' merupakan subjek karena letaknya di sebelah kiri frasa isih mencutake 'masih menggiyurkan' yang menduduki fungsi predikat. Ngemis 'meminta-minta' berasal dari bentuk dasar Kemis 'Kamis' mendapat prefiks $N$ - (ang-), prefiks ini bermakna melakukan pekerjaan seperti pekerjaan pada hari Kamis, yaitu meminta-minta. Sedang pada kalimat kedua kata nyadran menduduki fungsi subjek karena letaknya di sebelah kiri predikat yang diduduki oleh kata katindakake 'dilakukan. Fungsi keterangan pada kalimat tersebut diduduki oleh frasa rong dina. Proses pembentukan kata nyadran tersebut berasal dari bentuk dasar sadran 'suatu upacara tradisional di kuburan' mendapat prefiks $N$ - (any-) sehingga menjadi nyadran yang berarti melakukan kegiatan sadran.

\section{Verba Turunan sebagai Predikat}

Predikat dalam bahasa Jawa yang diduduki oleh kata yang berkategori verba turunan nampak pada kalimat berikut.
Wong alim
Subjek
kejiret
Predikat Pelengkap
'Orang alim terjerat nafsu' ( DL, 36, 3
Pebruari 2008: 3) 
Data di atas mengandung verba turunan yang menduduki fungsi predikat. Predikatnya kalimat di atas diduduki oleh kata kejiret 'terjerat' karena konstituen tersebut sebagai konsituen pusat dalam kalimat itu. Kemudian yang menduduki fungsi subjek adalah wong alim 'orang alim', dan nepsu 'nafsu' menduduki sebagai pelengkap. Kejiret yang menduduki predikat tersebut merupakan kata yang berkategori verba turunan. Kejiret berasal dari bentuk dasar jiret 'jerat' mendapat prefiks ke-.

\section{Verba Turunan sebagai Objek}

Dalam bahasa Jawa verba turunan dapat juga menduduki fungsi objek. Berikut kalimat yang objeknya berupa verba turunan.

$\frac{\text { Wis rong taunan }}{\text { Ket.waktu }} \frac{\text { panjenengane }}{\text { Subjek }}$
mulang $\frac{\text { maca }}{\text { Predikat Objek }}$
'Sudah dua tahunan beliau mengajar
membaca'

Kalimat tersebut terdiri atas wis rong taun 'sudah dua tahun' menduduki fungsi keterangan, panjenengane 'beliaunya' menduduki fungsi subjek dan kata mulang 'mengajar' sebagai predikat, sedang objeknya berupa kata maca. Kata maca 'membaca' menduduki fungsi objek karena terletak di sebelah kanan predikat yang berwatak aktif intransitif yaitu kata mulang 'mengajarkan'. Kata maca berasal dari bentuk dasar waca mendapat prefiks $N$ - (am-).

\section{Verba Turunan sebagai Pelengkap}

Dalam bahasa Jawa verba turunan juga dapat menduduki fungsi sebagai pelengkap. Berikut kalimat yang mengandung verba turunan sebagai pelengkap.

$\frac{\text { Bapake bocah-bocah }}{\text { Subjek }}$
$\frac{\text { ngrabisa mandheg }}{\text { Predikat }}$
Pelengkap

'Bapaknya anak-anak tidak dapat berhenti merokok'

Kalimat di atas mengandung subjek berupa bapake bocah-bocah 'bapaknya anak-anak', predikat berupa ora bisa mandheg 'tidak dapat berhenti', dan pelengkap berupa kata ngrokok 'merokok'. Kata ngrokok'merokok' yang menduduki fungsi pelengkap karena tidak menduduki fungsi subjek jika kalimat tersebut dipasifkan. Kata ngrokok 'merokok' berasal dari bentuk dasar rokok 'rokok' yang mendapat prefiks $N$ - (ang-), prefiks tersebut membentuk verba turunan aktif intransitif dengan makna melakukan pekerjaan/aktivitas merokok.

\section{Verba Turunan sebagai Katerangan}

Verba turunan yang menduduki fungsi kleterangan dalam kalimat berbahasa Jawa nampak pada kutipan berikut ini.

$$
\begin{aligned}
& \frac{A k u}{\text { Subjek Predikat }} \frac{\text { karep becik }}{\text { Objek }} \\
& \text { percayaa } \\
& \text { Keterangan }
\end{aligned}
$$

'Paman saya mempunyai kehendak yang baik percayalah' (DL 1326 Agustus 2008: 51)

Kalimat tersebut terdiri atas aku 'saya' yang menduduki fungsi sobjek, duwe 'mempunyai' menduduki fungsi predikat karep becik 'niat baik' mempunyai fungsi objek serta pecayaa 'percayalah menduduki fungsi keterangan yang menerang akibat dari niat baik maka percayalah dan letaknya dapat dipindah di sebelah kiri konstituen subjek atau di sebelah kanan subjek.

\section{SIMPULAN}

Verba mempunyai peranan penting dalam pembentukan suatu klausa atau suatu kalimat. Dalam klausa atau kalimat berbahasa Jawa banyak dijumpai adanya verba turunan. Penelitian verba turunan dalam bahasa Jawa ini dapat di- 
ambil simpulan beberapa hal. Pertama pembentukan verba turunan dalam bahasa Jawa sangat produktif. Hal itu tampak dari beragamnya afiks pembentuk verba turunan dalam bahasa Jawa. Prefiks pembentuk verba terdiri atas $N$-, maN-, ka-, ke-, di-l dipun, dan bawa ha. Infiks pembentuk verba turunan terdiri atas; -um-, dan -in-. Sufiks pembentuk verba turunan berupa-i,-a, -en, -an,-ana, -akelake. Konfiks pembentuk verba terdiri atas $k a-/-a n$, sementara afiks gabung pembentuk verba turunan berupa Ndigabung dengan -i atau -ake, -a, -na, - ana, atau di- digabung dengan -a, -na, in, atau dapat juga gabungan afiks -in-/ -ake, -in-l-ana, -um/ i. Kedua makna yang terkandung dalam verba turunan dalam bahasa Jawa adalah melakukan pekerjaan atau kegiatan baik yang disengaja maupun tidak disengaja, memakai atau mempunyai, perintah, pengharapan, menyebabkan sesuatu, pengandaian terkait dengan kegiatan, atau mempunyai makna dikenai perlakuan. Berikutnya verba turunan bahasa Jawa dalam suatu kalimat dapat menduduki fungsi sebagai subjek, predikat, objek, pelengkap, maupun keterangan.

\section{UCAPAN TERIMA KASIH}

Artikel ini disusun berdasarkan hasil penelitian yang dilaksanakan pada tahun 2008 dengan anggran DIPA FBS UNY. Ucapan terima kasih dismapaikan kepada DPP Penelitian FBS yang telah memfasilitasi penelitian ini. Ucapan terima kasih disampaikan juga kepada mahasiswa yang telah membantu mengumpulkan data serta kepada reviewer yang telah memberikan masukan terhadap artikel ini.

\section{DAFTAR PUSTAKA}

Karleni, Eni, 2005. “Verba Berpelengkap dalam Bahasa Indonesia Suatu Kajian Struktur dan Semantik". Litera Jurnal Penelitian Bahasa Sastra, dan Pengajarannya. Volume 4 Nomor 1 Januari 2005, halaman 1-10.

Moeliono, A dan S. Dardjowidjojo. 1988. Tata Bahasa Baku Bahasa Indonesia. Jakarta: Balai Pustaka

Nurhayati, Endang dan Siti Mulyani. 2006. Linguistik Bahasa Jawa. Yogyakarta: Bagaskara

Sudaryanto. (Ed). 1991. Tata Bahasa Baku Bahasa Jawa. Yogyakarta: Duta Wacana University Press.

Sasangka, Sry SatriyoTjatur Wisnu. 2001. Paramasastra Gagrag Anyar Basa Jawa. Jakarta: Yayasan Paramalingua. 